\title{
Types of identity among people in their late adulthood, who reside in both Polish and Czech parts of Cieszyn Silesia
}

Streszczenie: Tożsamość, jako definicja siebie, samookreślenie, jest pierwotnym doświadczeniem człowieka i podstawą kształtowania się jakości życia. Zmiana i ugruntowanie się tożsamości osób w wieku późnej dorosłości zamieszkujących polską i czeską część Śląska Cieszyńskiego dokonuje się w przestrzeni pogranicza państw, narodów, społeczności, kultur itp. Kreują ją wzajemne oddziaływania, relacje i więzi międzyludzkie, znaczenia, identyfikacje, elementy materialne oraz infrastruktura. Te warunki stawiają jednostkę przed koniecznością wyboru, aktywnego działania kreującego jej życie.

Niniejsze opracowanie jest komunikatem $\mathrm{z}$ badań przeprowadzonych w Cieszynie oraz Czeskim Cieszynie. Celem podjętych poczynań badawczych jest poznanie typów tożsamości u osób w wieku późnej dorosłości zamieszkujących polską i czeską część Śląska. Wyniki przeprowadzonych badań wskazują, że u osób w wieku późnej dorosłości zamieszkujących polską i czeską część Śląska Cieszyńskiego dostrzec można różne typy tożsamości: jednowymiarową, dwuwymiarową, wielowymiarową (wzbogaconą).

Słowa kluczowe: typy tożsamości, osoby w wieku późnej dorosłości, Śląsk Cieszyński

\section{Introduction}

An individual creates their identity when searching for answers to intriguing questions about the sense of existence. The creation of identity comes thanks to other people and the surrounding groups. A human being notices differences in others, own characteristic features or features of a group, which they identify themselves with. On such a basis own image is created.

"Personal identity of a human being is created thanks to characteristic human's need of searching and creating a sense of life. In connection with it, and as some kind of condition, social identity is created. An individual builds 
their "I" in the area which was established by groups and societies which influence each other. They provide categories to determine oneself in the context of group affiliation, as a result, a set of self-determinants is created which is used by an individual to describe oneself" (Szczurek-Boruta, 2014, p. 182).

Source literature presents different categories and types of identities, understood by Peter L. Berger and Thomas Luckmann as: "social creation, relatively persistent aspects of social reality (but the level of persistence is socially determined). As such, they are a matter of a kind of theorizing in every society, even if persistent and individual identity creation does not hide major problems" (Berger, Luckmann, 1983, p. 264).

\section{Research subject and the research}

The research was an attempt to find an answer to the following problem: What types of identities can be observed among people in their late adulthood, who reside Polish and Czech part of Cieszyn Silesia?

Based on source literature and results of other research, a thesis was assumed: among people in their late adulthood there can be recognized several types of identities: one-dimensional, two-dimensional and multidimensional (enriched). In the southern Polish-Czech borderline, Cieszyn Silesia is a peculiar example of the area, there is a tradition of multidimensional identity approach. Multidimensional identity is declared and presented by a young generation of Polish, Czech and it may concern also some of the adults in their late adulthood.

The results presented were gathered in research conducted for doctoral dissertation ${ }^{1}$. The research was based on a questionnaire, according to Krzysztof Rubacha typology, as a method of quantitative data gathering ( $\mathrm{Ru}$ bacha 2008,). The questionnaire was prepared in Polish for people who reside in the Polish part of Cieszyn Silesia and Czech for those who reside in the Czech part of the area.

In total 110 people were the subject of the research which was conducted in 2013 in Polish (Cieszyn) and Czech (Czech Cieszyn) parts of Cieszyn Silesia.

1 The topic was vastly described in the doctoral thesis by K. Jas: Sense of identity of people in their late adulthood - studies and experiences by the example of Cieszyn Silesia. The doctoral thesis was written under the direction of prof. dr hab. A. Szczurek-Boruta. University of Silesia Faculty of Ethnology and Educational Science in Cieszyn. 
The research involved people in late adulthood. The definition of late adulthood is interpreted as "the period of getting older which is traditionally called the elderly. The boundaries of this developmental period are from 55 to 60 years old and more" (Harwas-Napierała, Trempała, 2000, pp. 15, 263). At this stage of development, an individual summarizes their existence. This situation may cause further creative development or can influence negative tension which is a result of dealing with an identity crisis. Therefore, it seems interesting to become acquainted with the ways of dealing with problems in identity creation in such an age group.

The chosen area, Cieszyn and Czech Cieszyn are two neighboring towns, located in the historic area of Cieszyn Silesia. Cieszyn Silesia is a region situated both in Poland and in the Czech Republic - it is a point of contact, place of interfusion of traditions, customs, and behaviors of different cultural groups (Chlebowczyk, 1983).

Deliberately, there was applied finite population sample in the research (Pilch, Bauman, 2001). In the quantity research of elderly people, a method of non-random selection, random selection (in the age of late adulthood) and 'snowball effect' was used (Rubacha, 2008). In the quality research - representatives of subgroups - residents of Polish and Czech parts of Cieszyn Silesia.

To process the data statistic methods and techniques were used, eg. cluster analysis (method of classification of cases and variables, tree of connections, distance standards). The methodology enabled a holistic view of all established variables (Ferguson, Takane, 2004). The analysis was supported by STATISTICA 10).

One of the so-called classification methods was used - taxonomic, statistic method - cluster analysis. It enabled grouping of behaviors in relatively homogenous classes. As a result of agglomeration, a hierarchic tree graph was acquired. If clusters of similar items exist, the structure can be observed in a hierarchic tree graph, as separate branches. To link items, a method of weighted arithmetic means was applied. The length between the items was set as Pearson 1-r (factor of linear correlation) ( Frankfort - Nachmias, Nachmias 2001).

\section{Types of identities}

Nowadays it is more and more difficult to point the dominant type of identity or determine arguments for creating the specific type. It is the result of the fact that the creation of identity is a dynamic process, changeable, creating and nev- 
er-ending. In the process of creating own identity, it is important to search for own selfness in comparison to other individuals, groups, cultures or societies.

For the present study, theoretical considerations have referred to those determined, on the grounds of pedagogy, by Jerzy Nikitorowicz and Tadeusz Lewowicki types/profiles of identity: multidimensional identity, enriched identity, and multifaceted identity.

Jerzy Nikitorowicz emphasizes the process of creating oneself as an important aspect because of identifying oneself with national culture, openness to other cultures, cooperation, and compromise. The author mentions so-called identity templates, which were dominant types of identity in the past, so-called universal identities. He explains that "during the war, the type was a patriot, who risked life to protect Home Land, in peace and at the development times the type was a laborer, a community worker. In other times other types could be observed: a bureaucrat, a romantic, a positivist" (Nikitorowicz, 2003, p. 56).

Jerzy Nikitorowicz mentions identities where a differing factor is „multifaceted identity, created in the horizontal dimension (diachronic - variable) and vertical dimension (layered, interlapping with each other, mainly based on ethnic values)" (Nikitorowicz, 2003, p. 57). In such a presented identity, the author distinguishes three spheres: "inherited identity (social-cultural), individual identity (personal) and continually created identity (cultural, multicultural and intercultural). Those spheres are dominant in the process of creating a multifaceted identity, they condition objective and subjective human being functioning and cause that a person fulfils particular social roles, is positioned in society and has specified ambitions and needs" (Nikitorowicz, 2003, p. 57).

The kind of society in which an individual functions, the dominant message and the level of identification with them will influence the creation of identity. In such a context Jerzy Nikitorowicz point the following types of identity: ethnocentric identity, integrated identity (social - personal - cultural), scattered identity - multicultural, culturally confused identity - virtual.

Ethnocentric identity, associated with ethnocentrism, which is explained as „unity of positive attitudes towards national culture, which is central, where all others are assessed with its criteria and are often negatively perceived. In that dimension, identity will be described as relegation, ordering and not as processing, never-ending phenomenon. Stability, inner coherence, sense of individuality can be emphasized in that case. Two main aspects can be distinguished; elements of identity, its creation based on social interactions, strengthening by customs, values, and traditions transmitted from one generation another in a particular group" (Nikitorowicz, 2003, p. 59). 
The second type of identity defined by Jerzy Nikitorowicz is associated with the integrated identity (social - personal - cultural). Within the identity, there is observed "withdrawal from the narrow ethnocentric perspective of socializing and civilizing of a human being. The aspect of individuality and responsibility can be noticed, as well as human's strength and potential. Older generations introduce culture creatively to the younger ones, they engage them in cooperation and collaboration. Younger generations partially adopt rules and values after being acquainted with them. It causes mutual engagement and in a result processing of particular values. The matter of the kind of identity is a clear sense of who one is, despite inner changes, the environment changes, several social interactions" (Nikitorowicz, 2003, p. 59).

In multicultural societies there exists a necessity of acceptance of other cultures as equal. As a result, Jerzy Nikitorowicz suggests that "integrated identity can be called intercultural identity, a developing phenomenon, dynamic one, open to continuous creation and becoming complex, a changeable multidimensional matter which combines elements of individual and central cultural values of a group, which an individual belongs to and elements of conscious participation in other groups' values, and timeless European and planetary culture values" (Nikitorowicz, 2003, p. 62).

The following type of identity, mentioned by Jerzy Nikitorowicz, is scattered identity - multicultural. This kind of identity features "knowledge and consciousness of an individual concerning belongingness to several sociocultural groups, including the emotional and valuating meaning of the belongingness. Faster self-understanding is a result of pilling up of inner and outer contents which create identity both in horizontal - diachronic and vertical - layered dimension. The matter of this type of identity is continuous mobility, dynamics, openness, changeability. Therefore, it can be called a set of self-determiners connected with social categorization, attributing particular features that enable an individual to identify with certain groups" (Nikitorowicz, 2003, p. 63).

The last named identity is culturally confused one - virtual. Cultural confusion nowadays is a result of the creation of individual roles in the virtual world, which come from dissatisfaction with roles played in reality. Cultural confusion derives also from "intergenerational disunion, lack of leaders and cross-generational competition. Older generations, responsible for values transfer, are not able to fulfil their role because of: confusion, identity loss, lack of competences and lack of rules concerning processing particular values, consumerism and making money. While introducing to culture, the younger generation is treated 
like an immature social group, without cultural and social competences. As a consequence, cross-generational distance is becoming deeper, there occurs a lack of understanding and the transfer is one-sided. The teaching generation often seems to think that effective transfer happens when adaptation to social life occurs when appropriate social behaviors are gained; conformist behaviors are expected" (Nikitorowicz, 2003, p. 65).

Multifaceted identity cannot be omitted. It is understood by Tadeusz Lewowicki as "identity which harmoniously joins local, regional, state and national, European and even global dimensions. (....) it consists of mentioned dimensions of life" (Lewowicki, 2008, pp. 21-22).

Types of identities presented in this chapter are created by different factors: cultural content, persevering traditions, power, economic and political aspects.

\section{Types of identity among people in their late adulthood who reside in the Polish and Czech parts of Cieszyn Silesia based on own conducted research}

To establish types of identity among testees, in every single case several choices to a question: "Who are you?" were analyzed. To determine types of identity among testees, several choices to a question in the questionnaire "Who do you feel"? - were analyzed.

Figure 1. Types of identities among people in their late adulthood who reside in the Polish part of Cieszyn Silesia

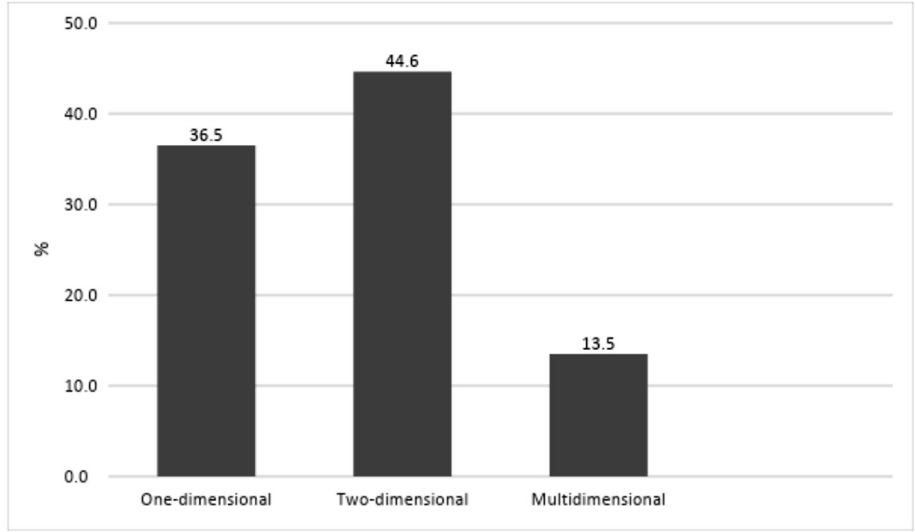

Source: Own research. 
The dominant type of identity among people in their late adulthood who reside Polish and Czech parts of Cieszyn Silesia is a two-dimensional identity (44,6\%). People belonging to this group declared that they feel both Polish and Silesian citizens (48,48\%); Polish and European (39,39\%), Polish and a citizen of the world $(6,06 \%)$.

$36,5 \%$ of testees present a one-dimensional identity (Polish national identity). $13,5 \%$ claim to have a multidimensional identity.

As noticed by Antonina Kłoskowska "participation in national society does not engage and exhaust the whole human being. What is more, he or she is a member of other communities, many collectivities, many other groups or societies" (Kłoskowska, 1997, p. 103).

The results of the research concern the last phase of multifaceted identity, according to Jerzy Nikitorowicz's idea, thus it is an illustration of consciously chosen and felt identity.

Figure 2. Types of identities among people in their late adulthood who reside in the Czech part of Cieszyn Silesia

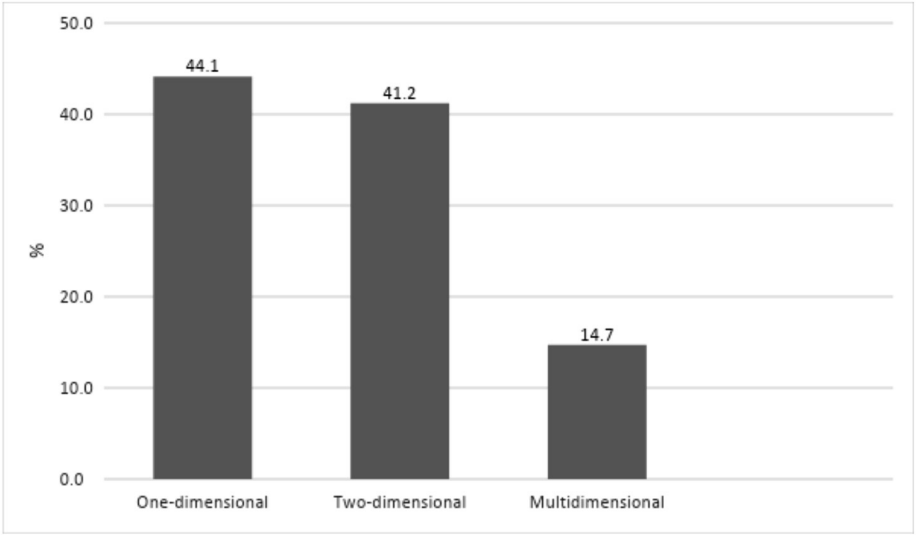

Source: Own research.

The biggest group of people in their late adulthood who reside in the Czech part of Cieszyn Silesia (44,1\%) presents a one-dimensional identity. Respondents declared that they feel Polish (64,0\%), Czech (21,0\%), Zaolziak (resident of lands beyond Olza River) (42,0\%), Silesian (21,0\%), European $(28,0 \%)$, a citizen of the world (14,0\%). To the group, there belong those who have Czech citizenship, Czech nationality and Polish nationality with an inner feeling of Polish identification. Two-dimensional identity is presented 
by $41,2 \%$ of people in their late adulthood, and multidimensional by $14,7 \%$ researched.

One-dimensional identity among seniors who reside Czech part of Cieszyn Silesia is surely the result of persevering the heritage of ancestors, roots of living at the borderland. But at the same time, it is the consequence of self-defence against the process of imposition of Czech culture, especially the Czech language, which was experienced by the respondents in their childhood while living in Czechoslovakia (currently the Czech Republic).

Consciously chosen and felt the identity of the group is also two-dimensional and multidimensional. As noticed by Barbara Grabowska "Pluralistic, multicultural state policy in the Czech Republic promotes intensive and positive relationships between different groups and persevering own identities by the groups at the same time. Membership in one group (national/ethnical) does not exclude membership in another group (national) and at the same time, there is a possibility of multiple experiences which enrich an individual and is a basis to create his / her identity" (Grabowska, 2015, p. 302).

Figure 3. Types of identities among people in their late adulthood who reside Polish and Czech parts of Cieszyn Silesia

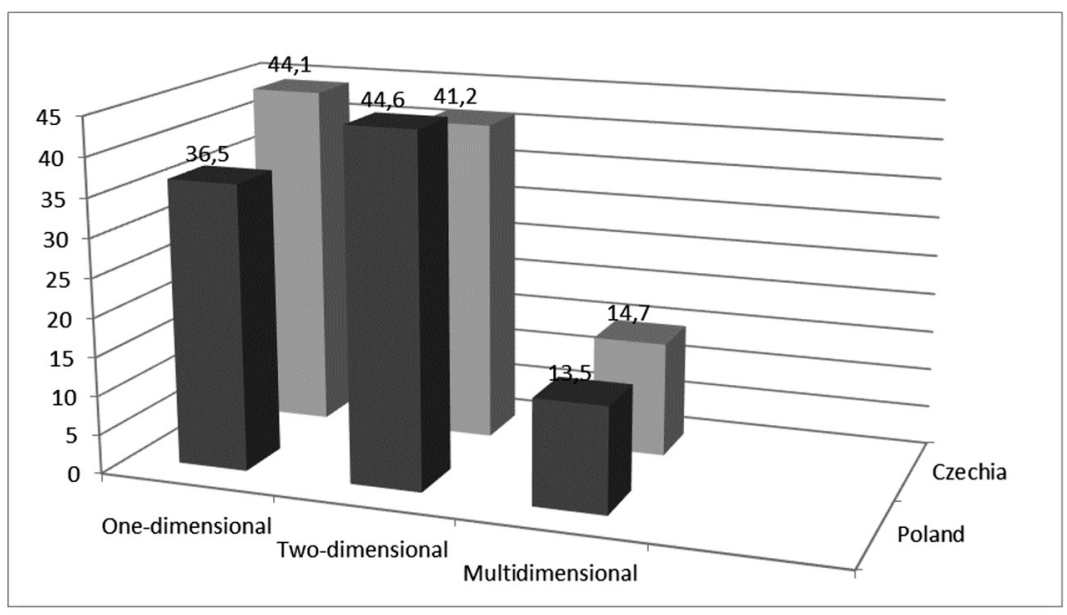

Source: Own research.

In the group of people in their late adulthood who reside Polish part of Cieszyn Silesia two-dimensional identity occurred to be dominant, whereas in the group of people in their late adulthood who reside Czech part of 
Cieszyn Silesia the dominant identity is one-dimensional. The sense of multidimensional identity is bigger among the Czech part of Cieszyn Silesia.

The results of the research conducted confirmed the thesis. Among the group of people in their late adulthood who reside Polish and Czech parts of Cieszyn Silesia different types of identities are observed: one-dimensional (38,9\%), two-dimensional (43,5\%), multidimensional (enriched) (13,9\%).

Figure 4. Types of identities among people in their late adulthood who reside Cieszyn Silesia

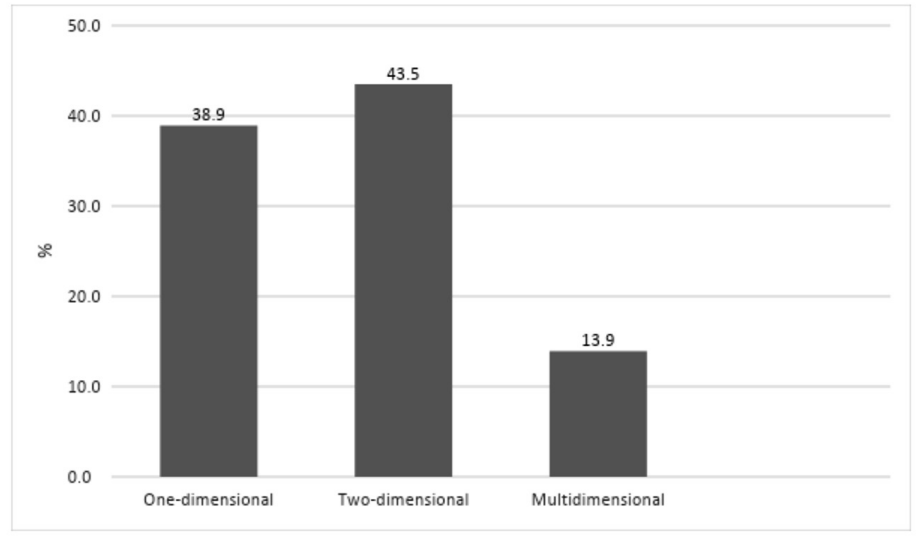

Source: Own research.

The results of the research depict that an elderly person identifies with many societies and groups at different levels. Antonina Kłoskowska writes that "an individual who exists in different cultures does not exhaust themselves concerning one particular culture, but they abstract some elements which are used for self-definition. All those elements adopted from different relations with some other psychological factors built their own identity of an individual" (Kłoskowska, 1997, p. 104).

Speaking about the identity of an individual there should be different cultures taken into consideration, and also there should be a place, role and function of national identity noticed. Jerzy Nikitorowicz (Nikitorowicz, 1995, pp. 82-83) in his concept draws attention to the multidimensionality of identity, "layeredness of identity”, but also to the possibility of interference of national cultures and creation of complex national identities.

To compile the data, there were used statistic methods and techniques, including cluster analysis (method of case or variables classification, tree con- 
nection, length measures) (Frankfort-Nachmias, Nachmias 2001). The cluster analysis allowed to group the variable into relatively homogeneous classes (Luszniewicz, Słaby, 2001).

Figure 5. Multidimensional identity (enriched) among people in their late adulthood who reside Cieszyn Silesia

Multidimensional identity (enriched) among people in their late adulthood who reside Cieszyn Silesia

Tree diagram

Weighted average connections

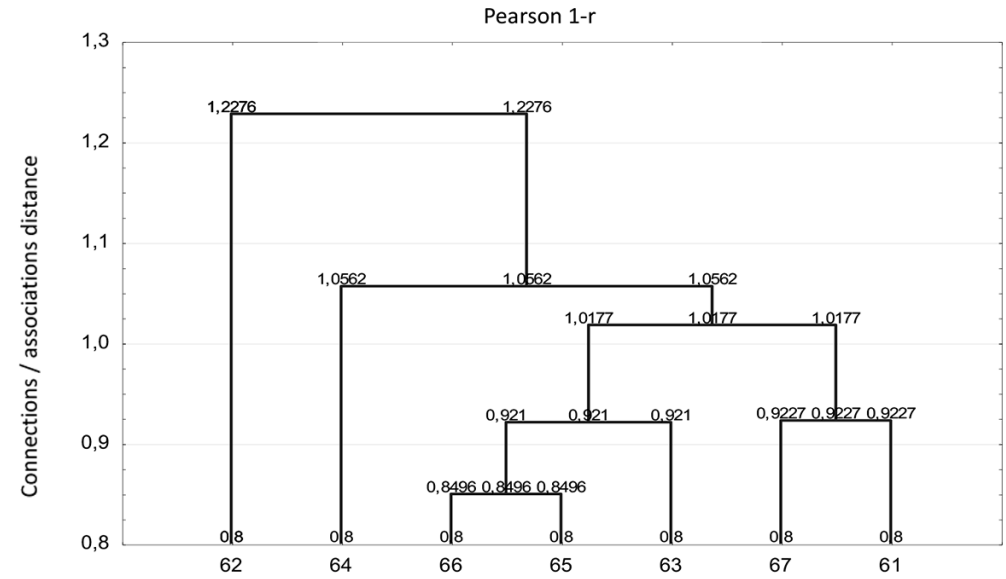

Source: Own research

Legend:

$61-$ Polish

$62-$ Czech

63- Zaolzianin (resident of

64 -Silesian

65- European

lands beyond Olza River)
66- a citizen of the world

67 - at the same level each

Source: Own research.

The results of cluster analysis confirmed the existence of multidimensional identity (enriched) among people in their late adulthood. The strongest relation (the smallest distance between associations) exists between a sense of European (65) and civil (66) identity $(\mathrm{r}=0,1504$, for $\mathrm{p}<0,05)$. Regional identity - Zaolzianin (63) (resident of lands beyond Olza River) ( $r=0,0079$, for $\mathrm{p}<0,05)$ is further from this cluster. The following identities are connected with the cluster: Polish national identity (61) at "the same level each" identity (67). The factor of the correlation between those two clusters structures is negative, it depicts a negative correlation, the substructures are exclusive. It is 
understandable in the group of researched citizens of Polish and Czech parts of Cieszyn Silesia. Regional Silesian and national Czech identities are further from this cluster. "Personality of a person living at the borderland - as Barbara Grabowska claims - is created in a multicultural environment. Specific conditions reflect in the social identity of the area residents. It is common to double or triple identities, but also (...) troubles in identity creation and developmental crisis are observed" (Grabowska, 2008, p. 13).

The sense of two - and multidimensional (enriched) identity helps people in their late adulthood, who reside at the borderland, to adjust to changing conditions of social, cultural, economic, political lives. Bond with many societies and groups is the result of actions undertaken in different groups, and it leads to multidimensional identity.

\section{Conclusions}

Diffusion of cultures observed at the borderland often causes scattered identity, riven one, but also open, multidimensional. Living at the borderland creates a demand for different types of identity creation that fulfil the individual, social, political and civilizational needs.

In the research conducted an answer to the following problem was established: What kind of identities can be observed among people in their late adulthood who reside Polish and Czech parts of Cieszyn Silesia?

People in their late adulthood who reside Polish part of Cieszyn Silesia declare two-dimensional identity (they feel Polish and Silesian; Polish and European, Polish and a citizen of the world), they present also the sense of one-dimensional identity (Polish national) and multidimensional identity.

The results are slightly different among people who reside in the Czech part of Cieszyn Silesia. The dominant identity is a one-dimensional one, but more people declare the sense of multidimensional one as well.

The results of research conducted confirmed the thesis: among people in their late adulthood who reside Polish and Czech parts of Cieszyn Silesia different types of identities can be noticed: one-dimensional, two-dimensional, multidimensional (enriched). Such a status is the result of the tradition of the multidimensional approach to identity in the southern Polish-Czech borderland, which peculiar example is Cieszyn Silesia. This fact was noticed by Tadeusz Lewowicki in the 90s of XX century; he wrote: "the dynamics of social life - in the matter of understanding of the traditional image of national identity and integration processes - is not limited to coexistence or impact 
of two tendencies, thus, firstly - to support or crystallize national identity (including state, ethnic, local, cultural, religious one, etc.) and - secondly to create a new transnational identity". The results of research conducted by Alina Szczurek-Boruta and Barbara Grabowska depict that part of the youth who reside in the researched area present multidimensional identity (Szczurek-Boruta, Grabowska, 2009).

The results of own research seem to testify the existence of specific identity templates, within the meaning presented by Jerzy Nikitorowicz, but also it is the proof of multifaceted identity of elderly people, which is a positive sign after identity crisis, which was accomplished in satisfactory living conditions, good quality of life. All that allows assuming their positive further development and success of social integration processes in Polish and Czech parts of Cieszyn Silesia, with mutual respect, persevering and maintain family, regional and national values.

\section{Bibliography}

Berger, P.L. i Luckmann, T. 1983. Społeczne tworzenie rzeczywistości. Warszawa: PIW.

Chlebowczyk, J. 1983. O prawie do bytu matych $i$ młodych narodów: kwestia narodowa i procesy narodotwórcze we wschodniej Europie środkowej dobie kapitalizmu (od schytku XVIII do początków XX w). Warszawa - Kraków: WN PWN.

Dyczewski, L. 2013. Tożsamość i patriotyzm. In: Nikitorowicz, J. ed. Patriotyzm i nacjonalizm. Ku jakiej tożsamości kulturowej? Kraków: Oficyna Wydawnicza „Impuls”, pp. 173-189.

Ferguson, G.A. i Takane, Y. 2004. Analiza statystyczna w psychologii i pedagogice. Warszawa: WN PWN.

Frankfort-Nachmias, C. i Nachmias, D. 2001. Metody badawcze w naukach spotecznych. Poznań: Wydawnictwo Zysk i S-ka.

Grabowska, B. 2008. Czynniki socjalizacyjno-wychowawcze w procesie kształtowania się tożsamości mieszkańców pogranicza. In: Lewowicki, T., Grabowska, B. i Gajdzica, A. eds. Socjalizacja i ksztattowanie się tożsamości - aktualne doświadczenia na pograniczu polsko-czeskim. Toruń: Wydawnictwo Adam Marszałek, pp. 11-22.

Grabowska, B. 2013. Poczucie tożsamości młodzieży uczacej się w szkołach $z$ polskim językiem nauczania na Białorusi, Ukrainie, $i$ w Republice Czeskiej. Toruń: Wydawnictwo Adam Marszałek. 
Harwas-Napierała, B. i Trempała, J. 2002. Psychologia rozwoju człowieka. Charakterystyka okresów życia człowieka. Warszawa: WN PWN.

Kłoskowska, A. 1996. Kultury narodowe u korzeni. Warszawa: WN PWN.

Lewowicki, T. 2008. O podstawowych warunkach pomyślnej pracy nauczycieli w sytuacji wielokulturowości. In: Lewowicki, T., Ogrodzka-Mazur, E. i Szczurek-Boruta, A. eds. Praca nauczyciela w warunkach wielokulturowości - studia i doświadczenia z pogranicza polsko-czeskiego. Toruń: Wydawnictwo Adam Marszałek, pp. 21-22.

Lewowicki, T. 1997. Wyznaczniki tożsamości narodowej (wiedza o determinantach tożsamości i zachowań tożsamościowych jako element edukacji). In: Jasiński, Z. i Kozłowska, A. eds. Tożsamość narodowa młodzieży na pograniczach. Opole: UO, pp. 35-40.

Luszniewicz, A. i Słaby, T. 2001. Statystyka z pakietem komputerowym STATISTICA ${ }^{T M}$ PL. Teoria $i$ zastosowania. Warszawa: Wydawnictwo C.H. Beck.

Melosik, Z. i Szkudlarek, T. 2008. Kultura, tożsamość i edukacja - migotanie znaczeń. Kraków: Oficyna Wydawnicza „Impuls”.

Nikitorowicz, J. 1995. Pogranicze. Tożsamość. Edukacja międzykulturowa. Białystok: Wydawnictwo Uniwersyteckie „Trans Humana”.

Nikitorowicz, J. 2003. Typy tożsamości człowieka w społeczeństwie zróżnicowanym kulturowo. Chowanna. 1 (20), pp. 50-66.

Pilch, T. i Bauman, T. 2001. Zasady badań pedagogicznych. Strategie ilościowe i jakościowe. Warszawa: Wydawnictwo Akademickie „Żak”.

Rubacha, K. 2008. Metodologia badań nad edukacja. Warszawa: WAiP.

Szczurek-Boruta, A. i Grabowska, B. 2009. Dynamika kształtowania się tożsamości młodzieży - ku tożsamości wzbogaconej. In: Lewowicki, T., Ogrodzka-Mazur, E. i Szczurek-Boruta, A. eds. Poczucie tożsamości i stosunek młodzieży do wybranych kwestii społecznych - studium z pogranicza polsko-czeskiego. Cieszyn - Warszawa - Toruń: Wydawnictwo Adam Marszałek, pp. 21-64.

Szczurek-Boruta, A. 2014. O przygotowaniu nauczycieli do pracy w warunkach wielokulturowości - konteksty opinie studentów, propozycje. Toruń: Wydawnictwo Adam Marszałek. 


\title{
Types of identity among people in their late adulthood, who reside in both Polish and Czech parts of Cieszyn Silesia
}

\begin{abstract}
Identity, as self-definition, self-determination, is the primary experience of a human being and the foundation for the quality life creation. Change and consolidation of identity among people in their late adulthood, who reside in both the Polish and Czech parts of Cieszyn Silesia, have been seen in different areas: at the border of two countries, among nationalities, societies, cultures, etc. They are created by mutual influence, relations, bonds, meanings, identifications, material aspects, and infrastructure. The conditions influence an individual and make them choose, adopt active actions that create their lives.

The following study is to present the results of research conducted in Cieszyn and Czech Cieszyn. The aim of the research is to recognize the types of identities among people in their late adulthood who reside in both the Polish and Czech parts of Cieszyn Silesia. The results of research conducted indicated that among people in their late adulthood who reside in the Polish and Czech parts of Cieszyn Silesia different types of identities can be noticed: one-dimensional, two-dimensional, multidimensional (enriched).
\end{abstract}

Keywords: identity, types of identity, people in their late adulthood, Cieszyn Silesia 